\title{
Conservation Tillage and Nitrogen Management for Sugarbeet Production
}

\author{
Chengci Chen, Reza Keshavarz Afshar \\ Montana State University, Eastern Agricultural Research Center \\ 1501 N Central Avenue \\ Sidney, MT 59270, USA \\ cchen@montana.edu; rezakeshavarz@montana.edu
}

\begin{abstract}
The conventional tillage for sugar beet production has many negative consequences for the soil and environment, including soil erosion, organic matter degradation, and fossil fuel consumption. Therefore, appropriate conservation tillage practices must be developed for sugarbeet production. The objective of this project is to develop an appropriate conservation tillage system for sugarbeet production in eastern Montana and optimize nitrogen management in accordance with the tillage system. We compared growth and yield of conventionally tilled sugarbeet with those under strip till and no-till. We also evaluated the response of sugarbeet to nitrogen rate $\left(56,112,168,224 \mathrm{~kg} \mathrm{ha}^{-1}\right)$ under aforementioned tillage systems to see if crop $\mathrm{N}$ requirement varies in different tillage systems. Results from 2016 show that tillage had a significant effect only on aboveground biomass and plant stand. Aboveground biomass and plant stand were higher in no-till compared to conventional tillage and strip tillage. It seems that better moisture availability in NT soil at seeding time led to better establishment in this treatment. No significant difference was found between tillage systems in terms of root yield, sucrose percent, and sucrose yield. This is very encouraging because NT can provide economic benefits (lower cost, less labor, less fuel consumption) as well as ecosystem services (less soil erosion, soil compaction, etc.) while producing similar yield as conventional tillage. No significant response was observed to increasing nitrogen rate. This shows that more efforts are needed to optimize nitrogen fertilization for sugarbeet under various tillage practices.
\end{abstract}

Keywords: conservation tillage, nitrogen, suagrbeet, ecosystem service

\section{Introduction}

Sugarbeet is an important economic crop in eastern Montana and west North Dakota [1] and [2] and conventional tillage is still widely used by sugarbeet growers in the region, which consists of five or more passes across a field for plowing or ripping, leveling (one to two times), and hilling. The conventional tillage has many unintended consequences for the soil and environment such as loss of organic matter and beneficial soil organisms, increased soil erosion and pesticide runoff, reduced soil fertility, loss of soil structure and porosity, compaction, surface crusting, the formation of plow pans, reduced root growth, and poor drainage. Eastern Montana has high wind in the fall and spring, and the conventional operation sometimes creates heavy dust storms, which not only blow away fertile surface soil and damage sugarbeet seedlings but also affect the traffic safety. Conventional tillage is also expensive, requiring large labor and fossil energy inputs. Therefore, development of appropriate conservation tillage practices for sugarbeet in our region is important. Nitrogen management for sugarbeet under conservation tillage also needs to be evaluated to increase nitrogen use efficiency and prevent nitrogen loss to the environment [2]. The objective of this multi-year project is to develop an appropriate conservation tillage system for sugarbeet production in eastern Montana and optimize nitrogen management in accordance with the tillage system.

\section{Materials and Methods}

A field experiment was carried out at the Eastern Agricultural Research Center irrigated farm in Sidney, MT. The soil is classified as Savage Clay Loam (Fine, smectitic, frigid Vertic Argiustolls). The soil has $26 \mathrm{~kg} \mathrm{ha}^{-1} \mathrm{NO}_{3}{ }^{-}-\mathrm{N}$ in $1.0 \mathrm{~m}$ profile, and the previous crop was spring wheat (Triticum aestivum L.). 
The experiment was conducted in a split plot arrangement based on a randomized complete block design with four replications. Main plots were tillage systems (conventional tillage or CT, strip tillage or ST, no-till or NT). Subplots were nitrogen rate $\left(0,56,112,168 \mathrm{~kg} \mathrm{ha}^{-1}\right)$ supplied with urea (46-0-0). In addition, $22 \mathrm{~kg} \mathrm{ha}^{-1}$ of 11-52-0 (N-P-K) and $45 \mathrm{~kg}$ ha${ }^{1}$ potash blended fertilizer was applied at planting.

Sugarbeet (cv. American Crystal S360) was planted on May 6, 2016 at a seeding rate of $12 \mathrm{seeds}^{2}$ (14 cm between plants and $61 \mathrm{~cm}$ between rows). Due to an unexpected problem in the irrigation system, the plots were not irrigated properly. Therefore, the plant establishment was not favorable. Plots were reseeded on June 3, 2016. During the sugarbeet growing period, glyphosate ( $\mathrm{N}$-(phosphonomethyl) glycine) was used for weed control, and fungicide Minerva-Duo (Tetraconazole \{1-[2-(2,4-dichlorophenyl)-3-(1,1,2,2-tetrafluoroethoxy) propyl]-1H-1,2,4-triazole and Triphenyltin hydroxide) was applied for disease control in late July. Sugarbeet was harvested on September 19, 2016. After harvest, sugarbeet roots were sent to Signey Sugar factory to extract juice and measure sugar content. Subsamples were taken and sent to AgTerra Laboratory (Sheridan, WY) for purity analysis. The growing season weather conditions are listed in Table 1. The total precipitation from May to August in 2016 was $370 \mathrm{~mm}$ which is close to 65 years average of $358 \mathrm{~mm}$. Irrigation is provided as needed by an overhead sprinkler system. Data were analyzed using Proc GLM of SAS. When F test showed a significant effect, $\operatorname{LSD}(\mathrm{P}<0.05)$ was employed to separate the means.

Table 1: Monthly weather data at Sidney during sugarbeet growing season in 2016.

\begin{tabular}{|l|c|c|c|c|}
\hline Month & Max Temp & Min Temp & Avg Temp & $\begin{array}{c}\text { Total } \\
\text { Rainfall }\end{array}$ \\
\hline & ${ }^{\circ} \mathbf{F}$ & ${ }^{\circ} \mathbf{F}$ & ${ }^{\circ} \mathbf{F}$ & inch \\
\hline April & 60 & 33 & 46 & 3.5 \\
\hline May & 71 & 43 & 57 & 2.1 \\
\hline June & 81 & 54 & 67 & 1.4 \\
\hline July & 85 & 57 & 71 & 2.7 \\
\hline August & 84 & 53 & 68 & 0.7 \\
\hline September & 70 & 47 & 59 & 2.6 \\
\hline Data from https://ndawn.ndsu.nodak.edu & \multicolumn{5}{l}{} \\
\hline
\end{tabular}

\section{Results}

The effect of tillage and nitrogen on sugrabeet yield and other important variables are shown in Table 2. Tillage had a significant effect only on aboveground biomass and plant stand. Aboveground biomass and plant stand were higher in notill compared to conventional tillage and strip tillage (Table 3). As mentioned previously, due to problems with irrigation system at the time of seed germination and establishment, it seems that better moisture availability in NT soil at this time led to better establishment in this treatment. No significant difference was found between tillage systems in terms of root yield, sucrose percent, sucrose yield and SLM (sugar loss to molasses). This is very encouraging because NT can provide economic benefits (lower machinery cost, less labor, less fuel consumption) as well as ecosystem services (less soil erosion and compaction, etc.) while producing similar yield as conventional tillage. No significant response was observed to increasing nitrogen rate. This shows that more efforts are needed to optimize nitrogen fertilization for sugarbeet under various tillage practices.

\section{Conclusion}

Sugarbeet planting with no-till practice is feasible. Preliminary results from this project demonstrate that no-till treatment had better seedling establishment and no yield reduction ompared to conventional tillage. 
Table 2: Effect of tillage and nitrogen rate on sugarbeet measured variables.

\begin{tabular}{|l|c|c|c|c|c|c|c|c|c|}
\hline $\begin{array}{c}\text { Source } \\
\text { Of } \\
\text { Variation }\end{array}$ & $\begin{array}{c}\text { Degree } \\
\text { Of } \\
\text { Freedom }\end{array}$ & $\begin{array}{c}\text { Aboveground } \\
\text { biomass }\end{array}$ & $\begin{array}{c}\text { Plant } \\
\text { density }\end{array}$ & $\begin{array}{c}\text { Sugar } \\
\text { content }\end{array}$ & $\begin{array}{c}\text { Root } \\
\text { YLD }\end{array}$ & $\begin{array}{c}\text { Sucrose } \\
\text { YLD }\end{array}$ & $\begin{array}{c}\text { Impurity } \\
\text { Value }\end{array}$ & $\begin{array}{c}\text { SLM } \\
\text { Extractable } \\
\text { Sucrose }\end{array}$ \\
\hline Rep & 3 & 0.775 & 0.572 & 0.207 & 0.951 & 0.906 & 0.220 & 0.207 & 0.366 \\
\hline Till & 2 & $\mathbf{0 . 0 0 3}$ & $\mathbf{0 . 0 4 0}$ & 0.334 & 0.755 & 0.848 & 0.687 & 0.710 & 0.833 \\
\hline N & 3 & 0.258 & 0.688 & 0.613 & 0.778 & 0.678 & 0.884 & 0.873 & 0.564 \\
\hline Till*N & 6 & 0.430 & 0.618 & 0.989 & 0.988 & 0.991 & 0.795 & 0.747 & 0.821 \\
\hline CV $(\%)$ & & 18.7 & 17.9 & 5.3 & 20.9 & 19.1 & 13.1 & 13.0 & 18.0 \\
\hline
\end{tabular}

Table 3: Main effect of tillage and nitrogen on sugarbeet measured variables.

\begin{tabular}{|c|c|c|c|c|c|c|c|c|c|}
\hline \multicolumn{2}{|c|}{ Treatments } & \multirow{2}{*}{ 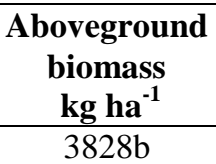 } & \multirow{2}{*}{$\begin{array}{c}\begin{array}{c}\text { Plants } \\
\text { ha }^{-1}\end{array} \\
61147 \mathrm{a}\end{array}$} & \multirow{2}{*}{$\begin{array}{c}\begin{array}{c}\text { Sugar } \\
\%\end{array} \\
17.4 \\
\end{array}$} & \multirow{2}{*}{$\begin{array}{c}\begin{array}{c}\text { Root YLD } \\
\text { t ha }^{-1}\end{array} \\
66.4\end{array}$} & \multirow{2}{*}{$\begin{array}{c}\begin{array}{c}\text { Sucrose } \\
\text { YLD } \\
\text { kg ha }^{-1}\end{array} \\
10651\end{array}$} & \multirow{2}{*}{$\begin{array}{c}\begin{array}{c}\text { Impurity } \\
\text { Value } \\
\%\end{array} \\
0.65\end{array}$} & \multirow{2}{*}{$\begin{array}{c}\text { SLM } \\
\% \\
0.97 \\
\end{array}$} & \multirow{2}{*}{$\begin{array}{c}\begin{array}{c}\text { Extractable } \\
\text { Sucrose } \\
\text { lb/ac }\end{array} \\
9792\end{array}$} \\
\hline Tillage & CT & & & & & & & & \\
\hline & ST & $3923 b$ & $54706 \mathrm{~b}$ & 17.1 & 69.9 & 10774 & 0.68 & 1.01 & 9897 \\
\hline & NT & $5005 a$ & $65104 a$ & 17.5 & 67.7 & 10726 & 0.65 & 0.97 & 9353 \\
\hline \multirow[t]{4}{*}{ Nitrogen } & N 50 & 4520 & 61254 & 17.5 & 70.6 & 11210 & 0.65 & 0.98 & 10245 \\
\hline & N 100 & 4451 & 63852 & 17.5 & 66.2 & 10429 & 0.64 & 0.97 & 9807 \\
\hline & N 150 & 4231 & 58416 & 17.1 & 65.0 & 10073 & 0.66 & 1.00 & 9100 \\
\hline & N 200 & 3903 & 58551 & 17.3 & 70.9 & 11200 & 0.66 & 0.99 & 9785 \\
\hline
\end{tabular}

\section{Acknowledgements}

The authors want to thank Dr. Bart Stevens and Bill Iverson for the help in strip tillage. This project is funded by USDA-WSARE Grant \#SW16-051.

\section{References}

[1] Montana Agricultural Statistics, [Online]. 2014, Available: http://www.nass.usda.gov/Statistics_by_State/Montana/Publications/Annual_Statistical_Bulletin/2014/Montana_An nual_Bulletin_2014.pdf

[2] D. A. Bangsund, N. M. Hodur, L. F. Leistritz, 2011, Economic Contribution of the Sugarbeet Industry to Eastern Montana and Western North Dakota, [Online]. Available: http://www.sidneysugars.com/media/242774/sid-impact2012.pdf

[3] J. L. A. Eckhoff and C. R. Flynn, "Sugarbeet response to nitrogen under sprinkler and furrow irrigation," Journal of Sugar Beet Research, vol. 45, no. 1/2, pp. 19-29, 2008. 